\title{
Electromiography of Superior Members in the Purpose of a Case of Poland Syndrome. Poland Syndrome Agenesia of Both Pectorals: With Patient Permission
}

\author{
Ángel Molina León* \\ Department of Clinic Neurophysiology, Santa Lucia Hospital, Cartagena, Spain \\ Submission: June 13, 2017; Published: June 19, 2017 \\ *Corresponding author: Ángel Molina León, Doctor the Clinic Neurophysiology Service, Santa Lucia Hospital, Cartagena, Murcia, Spain Clinical \\ Neurophysiology, Virgen De La Caridad Medical Center, Cartagena-Murcia, Spain, Tel: 968325258; Email: molinadelaasuncion@gmail.com
}

\section{Introduction}

Poland's syndrome is a rare malformation, prevalent in men, it is estimated that the incidence is 1 / 30,000 live births, which associates degrees of thoracic anomalies, and alteration of homolateral MMSS, the case that concerns us is bilateral, There is an important agenesis of the bilateral pectoral muscles. It is characterized by hypoplasia or aplasia, dysplasia, at the level of various muscle groups, for example the pectoralis major and minor, and other muscles of the scapular region. The absence of the pectoralis major muscle can be accompanied by hypoplasia of the subcutaneous tissue, and there is no axillary hair. It usually accompanies deformity of the chest wall and breast (from discrete hypoplasia or complete absence or amastia). It may have involvement at the ipsilateral level of the upper limb, with hypoplasia of the limb (brachydactyly), deformity of the forearm and wrist (ectromelia), attachment of the fingers (syndactyly) and even absence of the distal phalanges of Moebius syndrome in addition to the so-called winged scapula.

\section{Causes}

The syndrome of Poland has no hereditary basis. It develops as a result of an intrauterine developmental abnormality, in the sixth week of gestation, due to insufficiency, hypoplasia of the subclavian arteris that hinders the correct embryogenesis of the pectoral muscualtura and osteotendinous structures, producing musculoskeletal malformations.

Patient: with patient permission. Poland syndrome. Agenesia of both pectorals

It is a male, who works in the field, who has supplemented his pectoral muscle deficiency by doing sport; you can see a healthy and strong male. Very developed the muscles of the shoulder girdle and both arms. Bilateral winged scapula. Significant atrophy of both pecs. As can be seen in Figure 1. The alterations in this syndrome are muscular, osteotendinous, and cutaneous glandular nature. This syndrome owes its name to Alfred Poland that around 1841 when dissected a corpse described the agenesis of the pectoral.

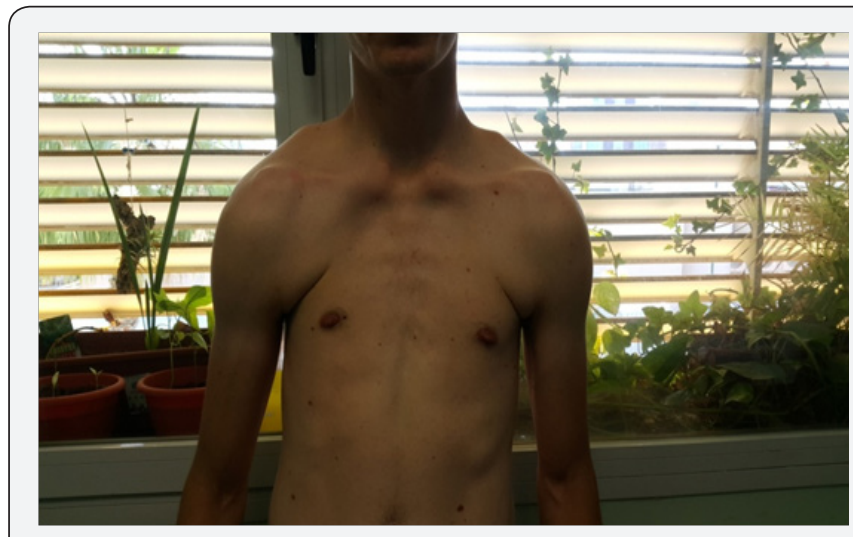

Figure 1: Poland syndrome. Agenesia of both pectorals with patient permission.

I. EMG: Patient with Poland syndrome, with limitation to anteversion and abduction of both shoulders, bilateral winged scapula, and muscular atrophy, hypogenesia and hypoplasia of both pectorals of the sternum-costal portion of the pectoralis major and left, referred for suspicion of plexus injury, Vs root, vs NEUROPATICA IN HAND DCHA VS STC DCHO. VS CERVICAL RADICULOPATHIES

II. Findings: EMG DELTOIDES AND BICEPS DCHO AND IZQ. . LOW CHRONIC NEUROPATHIC PATTERN IN PROBABLE RELATIONSHIP WITH CHRONIC RADICULOPATHY C5 BILATERAL LEVES. NO REAGANIZATION DATA.

III. EMG Both Pectorals: Hypogenesis and hypoplasia of both pectorals of the sternum-costal portion of the pectoralis 
major dcho. And left, and as a single manifestation EMG OF REGISTER THE PRESENCE OF A VERY ATROPHICAL PECTORAL MUSCLE, WITH PUM, NORMAL, WITH LENGTH AND DURATION WITHIN NORMALITY but less activity than in the rest of musculature explored. , Both at rest and in effort.

a. Conventional EMG: In the study with needle electrode at rest, no spontaneous activity was detected in explored muscles. In the qualitative study of motor units, signs of chronic denervation (units of increased size) have been detected in muscles innervated by different nerves but sharing C5 dcho root territory. And left (15 days - 5 MONTHS), with a slight gradation (deltoids and biceps) (with tracings at the maximum effort slightly simplified, normality in the rest of the muscles explored.) NO REGISTERED SIGNS OF ACTIVE DENERVATION THAT WILL SPEAK FOR AGUGDA- SUBAGUDE REAGUDIZATION (15 DAYS - 5 MONTHS). The EMG of the muscles of the left pectoral region shows SMOKED, NORMAL PUM, WITH AMPLITUDE AND DURATION WITHIN NORMALITY but less activity than in the rest of musculature (Supraspinatus, infraspinatus, rhomboid, normal) The EMG of the muscles of the left pectoral region shows SMALL, NORMAL PUM, WITH LENGTH AND DURATION WITHIN NORMALITY But less activity than in those in the rest of musculature explored, both at rest and effort ELECTROMIOGRAPHY OF SUPERIOR MEMBERS IN THE PURPOSE OF A CASE OF POLAND SYNDROME. POLAND SYNDROME. AGENESIA OF BOTH PECTORALS. WITH PATIENT PERMISSION.

b. EMG: Patient with Poland syndrome, with limitation to anteversion and abduction of both shoulders, bilateral winged scapula, and muscular atrophy, hypogenesia and hypoplasia of both pectorals of the sternum-costal portion of the pectoralis major and left, referred for suspicion of plexus injury , Vs root, vs NEUROPATICA IN HAND DCHA VS STC DCHO. VS CERVICAL RADICULOPATHIES•

c. Findings: EMG DELTOIDES AND BICEPS DCHO AND IZQ. . LOW CHRONIC NEUROPATHIC PATTERN IN PROBABLE RELATIONSHIP WITH CHRONIC RADICULOPATHY C5 BILATERAL LEVES. NO REAGANIZATION DATA.

a) EMG Both Pectorals: Hypogenesis and hypoplasia of both pectorals of the sternum-costal portion of the pectoralis major dcho. And left, and as a single manifestation EMG OF REGISTER THE PRESENCE OF A VERY ATROPHICAL PECTORAL MUSCLE, WITH PUM, NORMAL, WITH LENGTH AND DURATION WITHIN NORMALITY but less activity than in the rest of musculature explored. , Both at rest and in effort.

b) Conventional EMG: In the study with needle electrode at rest, no spontaneous activity was detected in explored muscles. In the qualitative study of motor units, signs of chronic denervation (units of increased size) have been detected in muscles innervated by different nerves but sharing $\mathrm{C} 5$ dcho root territory. And left (15 days - 5 MONTHS), with a slight gradation (deltoids and biceps) (with tracings at the maximum effort slightly simplified, normality in the rest of the muscles explored.) NO REGISTERED SIGNS OF ACTIVE DENERVATION, WHICH WILL SPEAK FOR AGUGDA- SUBAGUDE REAGUDIZATION (15 DAYS - 5 MONTHS) The EMG of the muscles of the left pectoral region shows SMOKED, NORMAL PUM, WITH AMPLITUDE AND DURATION WITHIN NORMALITY but less activity than in the rest of musculature (Supraspinatus, infraspinatus, rhomboid, normal) The EMG of the muscles of the left pectoral region shows SMALL, NORMAL PUM, WITH LENGTH AND DURATION WITHIN NORMALITY But less activity than in the rest of the musculature explored, both at rest and in effort. Skip left (Supraspinous, infraspinatus, rhomboid normal) (Figure 2).

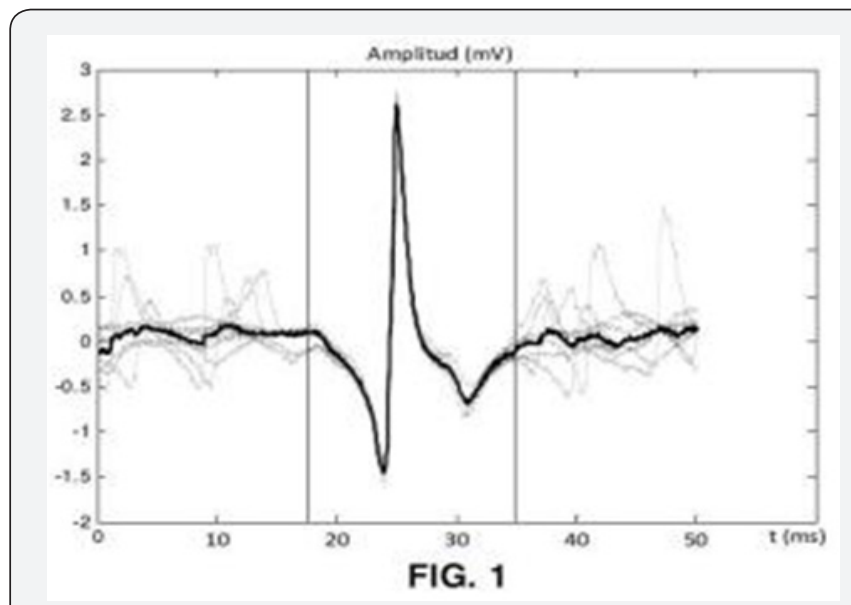

Figure 2: Pum within normal limits found in the pectoral muscle with a duration less than $12 \mathrm{msec}$. And up to $10 \mathrm{msec}$.

c) Sensitive ENG: N. Sensitive medium $1^{\circ}, 2^{\circ}, 3^{\circ}$, and $4^{\text {th }}$ finger dcho. And left. NO PR amplitude drop, temporal dispersion and moderate delay of the conduction velocity of the same in palm-wrist path. Dilated cubital nerve. normal. No sensitive amplitude drop and no latency delay. SENSITIVE NEUROGRAPHY OF BOTH MMSS:, MEDIUM, CUBITAL, LATERAL AND MEDIUM CUTANEOUSAL RADIAL DCHO AND IZQ. NORMAL. NO DATA OF DISTAL INJURY TO THE SENSITIVE RAQUIDE GANGLIO GIVE THE SENSITIVE NEUROGRAPHIC NORMALITY OF BOTH MMMSS. MEDIUM, CUBITAL RADIAL MUSCULOCIUTENO DCHO AND IZQ. NORMAL. EMG ESCAPULAR WAIST OF BOTH MMSS (ROMBOIDES, SUPRAESPINOSO, INFRAESPINOSO, TRAPECIO DCHO AND IZQ.) TO NORMAL LIMITS. AUSNEIC A CURRENT SIGN OF ACUTE DENERVATION NOT SUBAGUED, NOT CHRONIC.

d) Mixed ENG: palm-wrist of median nerve dcho. And left with delay of the driving speed of the PRMixto and not fall of the amplitude. Comparison of interpeak latencies between 4 th median-ulnar finger left. Is greater than $0.35 \mathrm{msec}$. In particular the current difference is 0.8 and $0.9 \mathrm{msec}$. On the right And left Sensitive fifth finger left and right And radial sensitive dcho and izq. normal. 
e) ENG motor: N. Medium and cubital motor dcho. And left normal. NO motor amplitude drop and no latency delay.

f) Winged scapula due to marked atrophy of both major and minor pectorals.

g) NO DATA OF PLEXOPATHY, DCHA AND IZQ. GIVING THE PRESERVATION OF ALL THE SENSITIVE POTENTIALS STUDIED IN BOTH MORE AND DEPENDENT OF THE TOP, MIDDLE AND LOWER TRUNKS.

h) The EMG of the muscles of the left pectoral region shows SMOOTH, NORMAL PUM, WITH LENGTH AND DURATION WITHIN NORMALITY but less activity than in the rest of muscualtura explored. , Both at rest and in effort. Musculature of the left scapular girdle (Supraspinatus, infraspinatus, rhomboids normal)

\section{Conclusion EMG}

Findings are compatible with: Chronic radiculopathy (more than 6 months of evolution) C5 left Of degree LEVE, old, without signs of exacerbation at the moment of the exploration. Bilateral carpal tunnel currently presenting a mild to moderate degree.
With data of mild neuroapraxy, without axonotmesis. Chronic mononeuropathy in manual worker. Winged scapula due to marked atrophy of both major and minor pectorals.

NO DATA OF PLEXOPATHY, DCHA AND IZQ. GIVING THE PRESERVATION OF ALL THE SENSITIVE POTENTIALS STUDIED IN BOTH MMSS AND DEPENDENTS OF THE TOP, MIDDLE AND LOWER TRUNKS. The EMG of the muscles of the left pectoral region shows SMOKED, NORMAL PUM, WITH LENGTH AND DURATION WITHIN NORMALITY but less activity than in the rest of musculature explored. , Both at rest and in effort. Musculature of the left scapular girdle (Supraspinous, infraspinatus, rhomboid normal) (Figure 3) CLINICAL AND EMG FINDINGS COMPATIBLE WITH AN SD. BILATERAL, SYNTHETIC POLAND, WITH HYPOGENICS AND HYPOPLASMS OF BOTH Pectoralis of the sternum-costal portion of the major and left pectoralis, AND AS THE ONLY EMG MANIFESTATION OF REGISTERS THE PRESENCE OF A PECTORAL MUSCLE WITH PUMP, NORMAL, WITH LENGTH AND DURATION WITHIN OF NORMALITY but less activity than in the rest of muscualtura explored. Both at rest and in effort. Musculature of the left scapular girdle (Supraspinatus, infraspinatus, rhomboids normal).

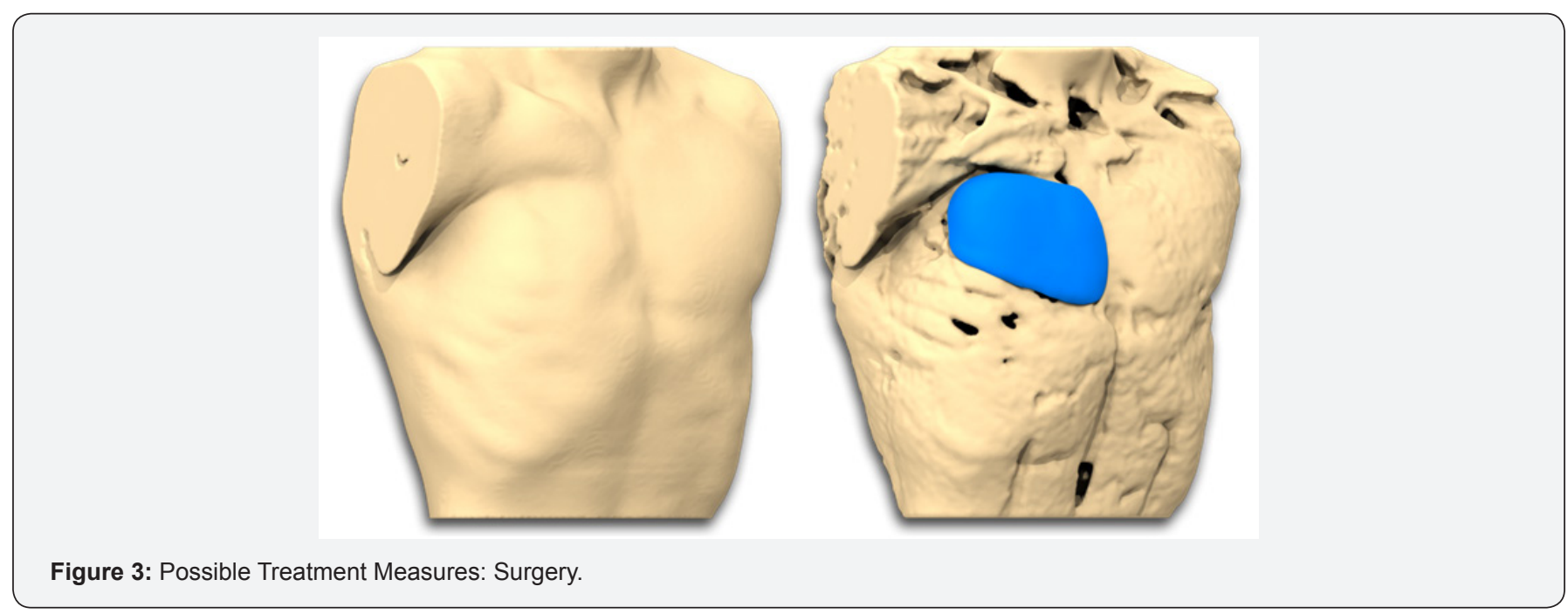

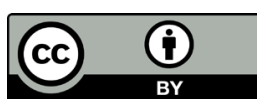

This work is licensed under Creative Commons Attribution 4.0 Licens DOI: 10.19080/OAJS.2017.04.555644

\section{Your next submission with Juniper Publishers} will reach you the below assets

- Quality Editorial service

- Swift Peer Review

- Reprints availability

- E-prints Service

- Manuscript Podcast for convenient understanding

- Global attainment for your research

- Manuscript accessibility in different formats

( Pdf, E-pub, Full Text, Audio)

- Unceasing customer service

Track the below URL for one-step submission https://juniperpublishers.com/online-submission.php 